\title{
A system for monitoring of operational safety of ferromagnetic structures
}

Janusz Juraszek

\begin{abstract}
The paper presents a system for monitoring of operational safety of ferromagnetic structures used in civil engineering, machine construction and power engineering. The system is based on sensors of the residual magnetic field (RMFM) distribution. A change in values of individual components of the residual magnetic field informs in advance about the appearance of areas with a raised level of stresses or stress concentration zones and identifies micro cracks. The paper presents numerous examples of identification of hazard areas both in machine construction (forging press drive shafts) and in civil engineering (transporter crane steel structure). The information obtained from the system for monitoring of operational safety of ferromagnetic structures has already made it possible to take appropriate preventive measures to avert a major catastrophe.
\end{abstract}

Keywords-safety of ferromagnetic structures, residual magnetic field, micro cracks

\section{Introduction}

Elements of machines and structures are subject to a natural process of degradation as a result of use as well as environmental conditions in which they are placed, which leads to wear and ultimately failure. In the light of the above, preventative methods are employed to maintain machines and structures, which to a large extent rely on periodic exchange of consumable parts. As can be seen from research conducted by industrial plant maintenance services, for example, $34 \%$ of roller bearings are removed too early but circa $66 \%$ too late contributing to the development of serious faults. The cause of such state of things often lies in the lack of ability to evaluate the actual technical condition of the unit. Imperfection of the recent diagnostic methods cause continual development of the research methods of non-destructive diagnostics. In order to carry out the diagnostic activities it is necessary to conduct analysis of the specific unit as well as the signals received from the unit. In the recent years considerable increase in the interest in nondestructive diagnostics of units has been noticed, which assess the current technical condition of the tested unit against failure occurrence or destruction the very object. The activity consists in detection, by means of recording, processing and analysis of signals emitted by the tested unit. It has been stated that there exists a relationship between technical condition of construction and the external signals of a unit represented by certain physical quantities.

An ever increasing awareness of need to develop advanced diagnostics systems leads to creation more up to date and innovative research concepts. Despite such a

Janusz Juraszek, University of Bielsko-Biala Poland development of testing methods, we are still faced with unforeseen disasters with tragic consequences:

Maritime disasters:

14.01.1993 - sinking of Jan Heweliusz ferry - 55 casualties, 10 missing.

Rail disasters:

03.06.1998 - derailing of a train in Enschede - 101 casualties, 300 injured.

Civil engineering disasters:

14.02.2004 - collapse of a glass/concrete/metal dome roof at the Transvaal swimming pool -28 casualties, 110 injured.

17.03.2005 - collapse of a Leroy-Merlin hypermarket roof in Gdańsk

28.01.2006 - collapse of a roof at the Katowice International Trade Fair -65 casualties, 170 injured.

\section{Residual magnetic field method (RMF)}

Disasters are unavoidable, they always happened and we may be certain that they will also take place in future. However, we should strive to limit them as much as possible by introducing new diagnostic methods. One of such methods is the residual magnetic field method (RMF). It is crucial to detect the critical or strained areas, that is areas with dense concentration of stress, well in advance which can allow to take necessary action and help to avoid major economical and human losses. The residual magnetic field is a method making use of the information coming from the magnetic field emission of the investigated object [3,5,17].

The physical fundamentals of RMF comprise of $[1,10]$ :

- magneto elastic effect - Villari effect,

- the forming of domains and domain boundaries in the areas of stress accumulation occurrence,

- effect of a stray magnetic field caused by non uniform magnetic properties in the material,

- existence of a weak external geomagnetic field.

The magneto elastic phenomenon, otherwise known as the Villari effect discovered in 1865 relies on the change in the magnetization degree of a given element as a result of loading. If a ferromagnetic material is placed within a weak external magnetic field, then under the influence of stress its magnetization will change. As a result, cyclical stress $\Delta \sigma$ occurring at any point in the structure (which is in the geomagnetic field) will cause a local increase of the residual induction. This phenomenon is inverse to the magnetostriction phenomenon $[2 ; 3,4,5$,$] . The SMLF occurring above the fault$ 
has a similar distribution to the magnetic field of a permanent magnet. Above the fracture edges, the normal component reaches its maximum values and passes zero in the middle of the defect. The tangential component reaches a maximum above the middle of the defect (Fig. 1). Opposite edges of the fracture behave like poles, as a result of which a small magnet of the same width as the fracture is created. As a result of stress on the material within which a defect exists, the degree of magnetization of this element increases and by the same the intensity of the filed strayed by the defect also increases $[1,6,7,8,9,10]$.

The creation of a stray magnetic field is a consequence of the appearance of induction component perpendicular to the surface of the tested element. This component appears due to the induction stream inside the element coming upon an area of a different magnetic permeability. [18]
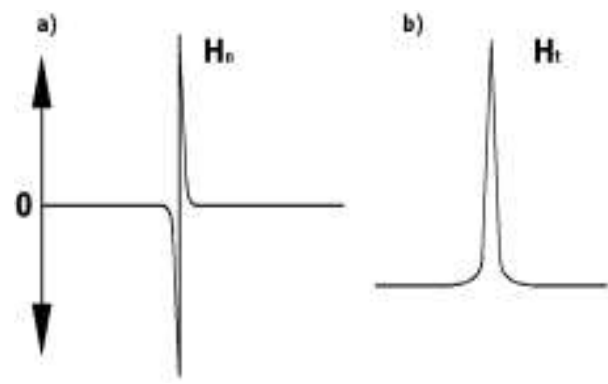

Figure 1. Model distribution of OSMF components above a defect a) normal component; b) tangential component

In accordance with (referring to magnetism) $H_{n}=\frac{1}{\mu_{0}} B_{n}$ we can state:

$$
H_{n} \sim \frac{1}{\mu_{0}} \cdot \lambda_{H, T} \cdot \Delta \sigma
$$

As can be seen from the above equation the normal component $\mathrm{H}_{\mathrm{n}}$ of OSMF is directly proportional to the change in stress $\Delta \sigma$ and is dependent upon the sensitivity of the magneto-elastic effect of the investigated element. That is why $H_{n}$ is used to evaluate the deformation degree and stress in the material [7].

The close relationship between the $\mathrm{H}_{\mathrm{n}}$ component and stress $\sigma$ or deformation $\varepsilon$ is dependent upon a number of factors: intensity of the magnetizing field, type of material, temperature as well as the type of deformation (tensile, compression, complex states). That is why for a quantitive evaluation of the indications performed using MMMM the relationships worked out for various elements are used, taking into consideration the working conditions and test conditions [18].

\section{III. . Experimental details}

\section{A. Welded joints}

In order to complete this examination, flat welded samples made of $\mathrm{P} 265 \mathrm{GH}$ material were prepared specially shaped to fit for mounting the samples in currently certified "INSTRON 1603" fatigue testing machine for dynamic tests The examination were conducted in the Stanislaw Staszic Institute of Iron Metalurgy in Gliwice [10,11]. On the basis of strength class and the graph of fatigue resistance ratio to the number of cycles a number of fatigue tests cycles were acknowledged for sample no $1=3 \times 10^{5}$ and for sample no $2=6 \times 10^{5}$

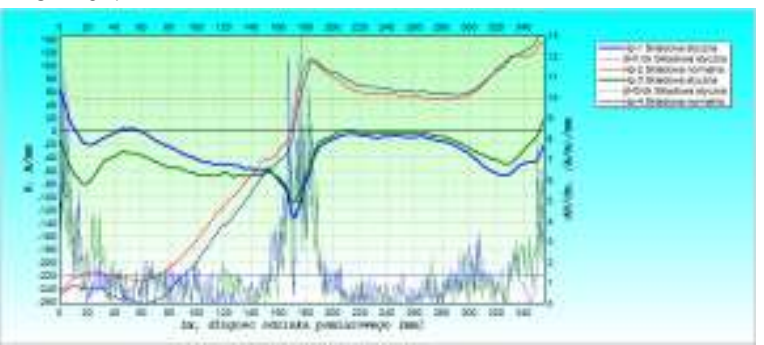

Fig. 2.. Magnetogram for sample no 1 after fatigue test $\left(3 \times 10^{5}\right.$ cycles) with $\mathrm{Ht}$ tangent compound gradient

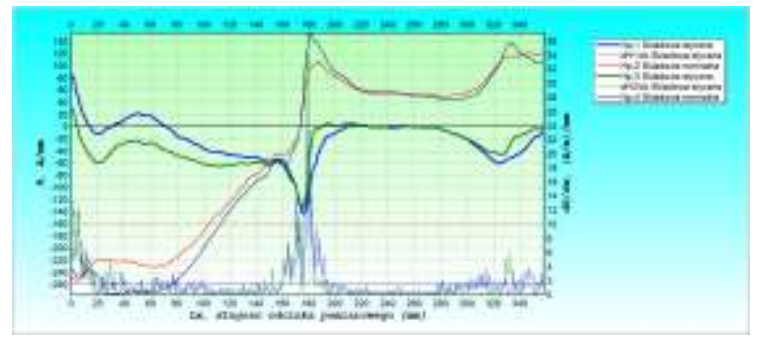

Fig. III. Magnetogram for sample no 2 after fatigue test $\left(6 \times 10^{5}\right.$ cycles) with $\mathrm{Ht}$ tangent compound gradient

Maximum value of magnetic field intensity for the tangent compound and its maximum gradient correspond to the place of transition of the detector over the weld (fig.2,3). Also in this area, significant increase of maximum gradient value of the tangent compound occurred $-18(\mathrm{~A} / \mathrm{m}) / \mathrm{mm}$ before the test; $36(\mathrm{~A} / \mathrm{m}) / \mathrm{mm}$ after the test.

\section{B. Crank shafts of forging presses}

A crank shaft of forging press (fig.4)with operational load of 500T was specified for conducting examination with the Magnetic Memory Method [13,14]. 


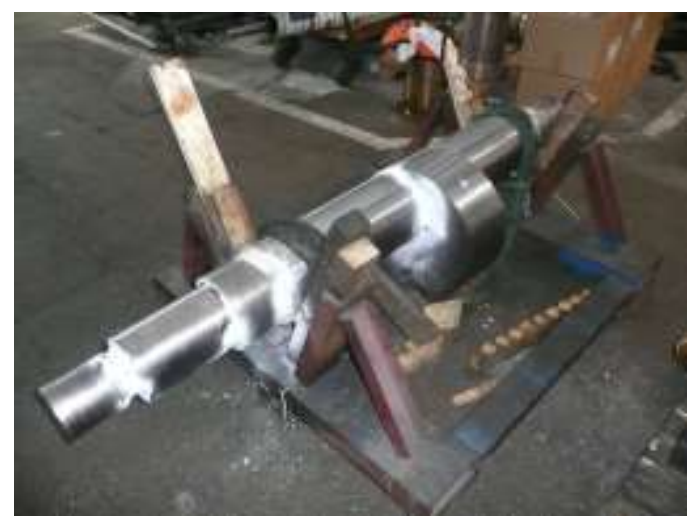

Fig. 4. Eccentric of the crank shaft with detected crack on the left side (clutch side

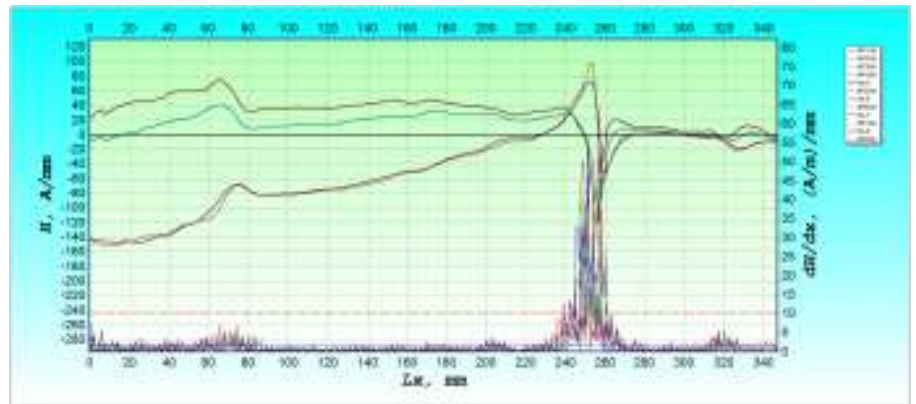

Figure 5. Graph of magnetic field distribution obtained as a result of scanning over the area of the border point of cracking confirmed with the MT method. (left side)

Stress Concentration Zones (SCZ) are clearly visible on the all above magnetograms over the line of cracking made as the result of examination with magnetic particle powder method. The areas of stress concentration are also visible beyond the line of crack detected and shown by MT method which confirms the fact of existing crack in the further part of the eccentric material. Values of gradients of magnetic field intensity $100 \mathrm{~mm}$ away from the extreme points of the crack similar to the values of results of measurement with determined points fig. 5 .

Results received with MMM method confirm the fact of existing a crack in the areas beyond the visible crack from the magnetic particle powder method. In the figure the component gradient is shown on fig. 6 .

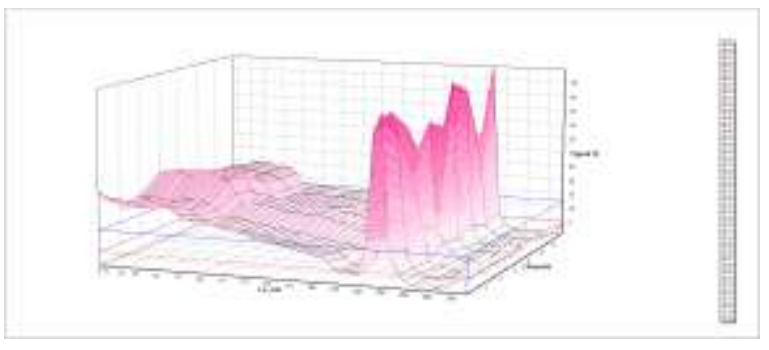

Fig.6. Distribution of the tangential and normal component gradient of the magnetic field
Study of the overhead travelling crane beam

The subject of the study were overhead travelling cranes located in two different countries. One of the cranes operated in a mine and was used to move coal from a storage. The other was used for handling coal in the processing department. Both structures belong to the overhead cranes group. The crane working at the mine has undergone modernization. Before starting the studies, it is necessary to the technical documentation of the overhead cranes carefully. A very important issue is analyzing any design changes made during the operation of the facility. The analyzed coal transport crane crane was built in 1980 [14-21]. It consists of two 13-span assemblies made of girder crane beams supported on truss structure pillars. The length of one span is approximately $12 \mathrm{~m}$ - Fig.1. The width of the crane is $32.01 \mathrm{~m}$ and the height of crane bridge from the top of the foundation bases to the upper foot of crane beam is $8.37 \mathrm{~m}$. Raising the level of safety of transport equipment, in particular handling equipment, which are often special-purpose structures, forces the implementation of new technologies of studying ferromagnetic structures. Such a new implementation is to studying the safety of the crane using the RMF method. The span with the highest load was checked. A defect in the middle part of its span was located - fig 7,8.

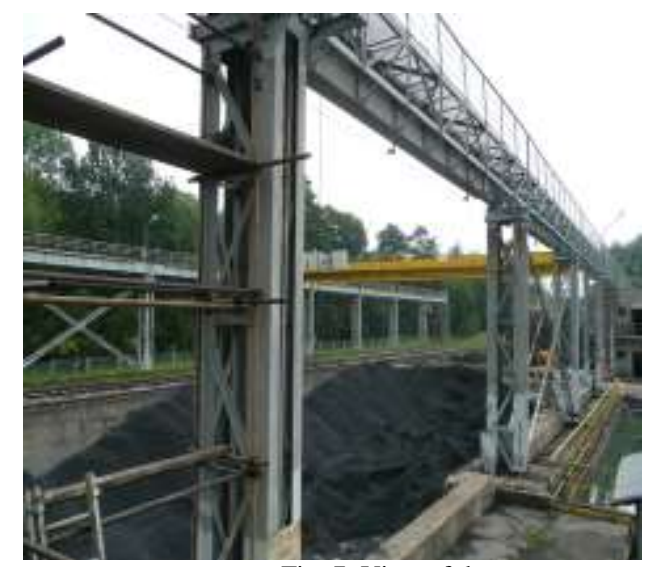

Fig. 7. View of the crane

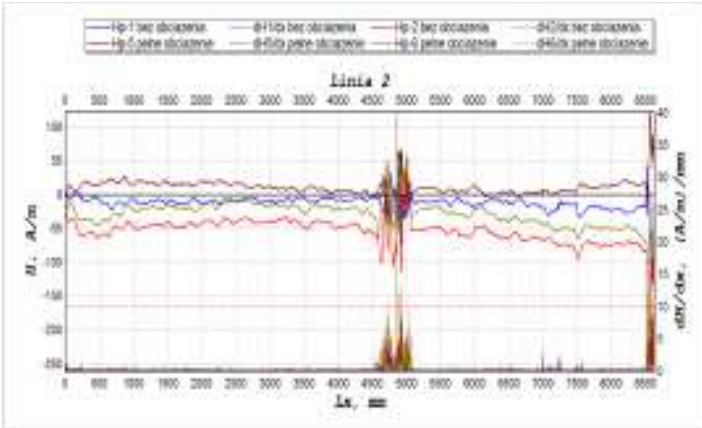

Fig. 8. Magnetogram with a defect in the middle part of the most heavily loaded span 


\section{Summary}

The RMF method presented at work significantly contributes to improving the operational safety of ferromagnetic structures. The examples of effective detection of cracks in shafts of presses and cracks in crane beams protected the analyzed structures from a major disaster. RMF method enables early detection of stress concentration areas a priori, that is, even before the first micro-cracks appear, which allows taking appropriate precautionary measures. This method is a valuable supplement to other diagnostic methods.

The paper presents an analysis of the universality of the RMF method including the solutions: The method identifies the higher levels of stress concentration zones in ferromagnetic elements of machines and structures, reconstructing the history of loading, detects a priori dangerous places even before the formation of the first microcracks,

\section{References}

[1] G. Eason, B. Noble, and I. N. Sneddon, "On certain integrals of Lipschitz-Hankel type involving products of Bessel functions," Phil. Trans. Roy. Soc. London, vol. A247, pp. 529-551, April 1955. (references)

[2] A. Adamiec, J.Juraszek, M. Rams: Zastosowanie MMM do badania wpływu obróbki cieplnej na poziom wytężenia dennic zbiorników ciśnieniowych, Mat. konf.: IV Międzynarodowa konferencja, Bezpieczeństwo pracy urządzeń transportowych $\mathrm{w}$ górnictwie, 5-7 listopada 2008, Ustroń.

[3] A.Adamiec, J.Juraszek J., M.Rams:, Zastosowanie MMM do analizy stref koncentracji naprężeń po wytłoczeniu dennicy, Mat. konf.: IV Międzynarodowa konferencja, Bezpieczeństwo pracy urządzeń transportowych w górnictwie, 5-7 listopada 2008, Ustroń.

[4] J.Deputat ., Podstawy metody magnetycznej pamięci metalu, Dozór techniczny, $\mathrm{Nr} 5 / 2002$

[5] X.Ding, J.Li., F.Li F,: Magnetic memory inspection of high pressure manifolds, Mat. konf.: 5th International Scientific-Technical conference „Equipment and structures diagnostics using the magnetic memory of metal", 17-19 luty, 2009, Moskwa

[6] A.Dubov: Diagnostyka wytrzymałości oprzyrządowania i konstrukcji z wykorzystaniem Magnetycznej Pamięci Metalu cz. 1, Dozór techniczny, $\mathrm{Nr} 1 / 2002$

[7] A.Dubov: Diagnostyka wytrzymałości oprzyrządowania i konstrukcji z wykorzystaniem Magnetycznej Pamięci Metalu cz. 2, Dozór techniczny, $\mathrm{Nr} 2 / 2002$

[8] A.Dubov: Physical base of the metod of metal magnetic memory, Mat. konf.: AMAS Course on Nondestructive Testing of Materials, NTM'02, 20-22 maj 2002, Warszawa

[9] A.Dubov: Principal features of metal magnetic memory metod and inspection tools compared to knowi magnetic ndt methods, Materiały firmy Energodiagnostyka- Moskwa/Warszawa

[10] A.Dubov: Zapytania o fizyczne podstawy metody magnetycznej pamięci metalu, Materiały firmy Energodiagnostyka- Moskwa/Warszawa

[11] J.Juraszek , A.Grzywa: Praktyczne przykłady zastosowania metody magnetycznej pamięci metalu (MMPM). Monografia: Innowacyjność akademicka - nowe wyzwania dla nauki i przedsiębiorczości. Strona 5177. ISBN 978-83-62292-50-9

[12] J.Juraszek., A.Grzywa : Światlowody z siatka Bragga do pomiaru odkształceń metoda diagnostyczna XXI wieku. Monografia: Innowacyjność akademicka - nowe wyzwania dla nauki i $\begin{array}{lllr}\text { przedsiębiorczości. } & \text { Strona } & 77-93 . & \end{array}$ ISBN 978-83-62292-50-9

[13] J.Juraszek.Innowacyjne, nieniszczące metody badań diagnostycznych ATH, 2013
[14] J.Juraszek, A.Grzywa, R.Żurek: Badanie próbek krzyżowych Metoda Magnetycznej Pamięci Metalu oraz Cyfrowej Korelacji Obrazu. Zeszyty naukowe BOSMAL Bielsko-Biała, Bielsko-Biała - kwiecien - 2015

[15] J.Juraszek., A.Grzywa: Badanie złaczy spawanych Metoda Magnetycznej Pamięci Metalu (MMPM).V Międzynarodowa Konferencja bezpieczeństwa pracy urządzeń transportowych w górnictwie. Materiały konferencyjne. Ustroń - listopad - 2015

[16] J.Juraszek., A.Grzywa.: Wykorzystanie nieniszczacej Metody Magnetycznej Pamięci Metalu do badania bieżni tożysk tocznych silników spalinowych oraz tożysk wałów napędowych elektrowni wiatrowych.VI Międzynarodowa Konferencja bezpieczeństwa pracy urządzeń transportowych w górnictwie. Materiały konferencyjne. Ustroń - listopad - 2010

[17] A. Kawka: Zastosowanie metody magnetycznej pamięci metalu do badania stanu zmienności naprężeń $w$ cięgłach nośnych naczyń wyciagowych, Mat. konf.: IV Międzynarodowa konferencja, Bezpieczeństwo pracy urządzeń transportowych $\mathrm{w}$ górnictwie, 5-7 listopada 2008, Ustroń

[18] W. Brachaczek, The hydrophobicity of renovation plaster In manufacturing technology optimized by statistical methods, Construction and Building Materials, 49 (2013) 572-582.

[19] W. Brachaczek, The modeling technology of protective silicone coatings in terms of selected physical properties: Hydrophobicity, scrub resistance and water vapor diffusion, Progress in Organic Coatings Volume 77, Issue 4, (2014) 859-867.

[20] W. Brachaczek, Investigating the impact of silicone-organic polymers with different chemical structures on water vapour permeability in silicone paint coats, Progress in Organic Coatings Volume 77, Issue 4, (2014), 609-615,

[21] J.Łukaszewicz, Z.Łapiński Z., Badania metoda pamięci magnetycznej próbek stalowych poddanych naprężeniom zewnętrznym, Wojskowy Instytut Techniczny Uzbrojenia, Zeszyty naukowe, Nr 99/2015

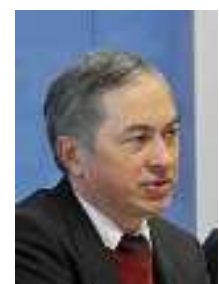

Professor Janusz Juraszek is Head of the Institute of Civil Engineering of the University of Bielsko-Biała. He deals with issues concerning operational safety in technology, including civil engineering and machine construction. He has proposed a system based on FGB sensors and optical fibres using the OTDR technology intended for monitoring the safety of structures used in civil engineering, machine construction and power engineering. The system is based on the residual magnetic field sensors and allows an analysis of operational safety of ferromagnetic structures, which is very important before first micro cracks arise. In 2014 in the USA he received the prestigious Horace Pubs award for the best publication on wire ropes. He also deals with smart materials with optical fibres using the FBG and the OTDR technologv. 